$\left.\begin{array}{|l|c|c|}\hline \begin{array}{l}\text { Word and Text } \\ \text { A Journal of Literary Studies and Linguistics }\end{array} & \text { Vol. XI } & \text { December / 2021 }\end{array}\right)$

\title{
Homofaunie: Non-human Tonalities of Listening in Derrida and Cixous
}

\author{
Naomi Waltham-Smith \\ University of Warwick \\ E-mail: naomi.waltham-smith@warwick.ac.uk
}

\begin{abstract}
In L'animal que donc je suis Jacques Derrida suggests that the question of what would be proper to the animal should 'change tune'. I read this extraordinary passage, in which Derrida calls for us to lend an ear to an 'unheard-of music' that neither emancipates the non-human nor condemns it to inarticulate noise, in conjunction with the nexus of animality, telephony and the cri de la littérature that unfolds in Hélène Cixous's writing, exploring the significant role assumed by the sonorous in these descriptions of non-human life. For Cixous, the telephonic power of near-instantaneous substitution and of prostheticity is inseparable from the sounds produced by the coterie of animals that populate the writings of these two authors. What is intriguing is that this bestiary is almost always said with a certain homonymy or homophony. Hence this article traces what I dub an 'homofaunie' echoing Cixous's series of puns and neologisms such as '( $t$ )elefaun' and '( $t$ )elephantasy' that capture Derrida's attention. The article asks what is at stake for theorizing non-human life - not just animal but also plant and so-called inanimate life - if the mode of questioning is to be redirected by a specifically aural attunement in which listening itself is retuned under the guidance of untranslatable homophony.
\end{abstract}

Keywords: animality, aurality, deconstruction, homonymy, homophony, listening, posthumanities

The issue of animality became an increasing preoccupation for Derrida in his later life. As he observes in L'animal que donc je suis, though, 'Une telle compagnie, j'y songeais depuis toujours sans doute, bien avant la visitation d'innombrables bêtes qui surpeuplent maintenant mes textes [I was no doubt always thinking about such a company, well before the visitation of the innumerable critters that now overpopulate my texts]. ${ }^{1}$ Wary of the fabulization (another common theme in his thought) and hence the anthropomorphism and domestication of traditional bestiaries, he goes on in a very lengthy paragraph to list the 'horde d'animaux [horde of animals]' in the menagerie of his earlier texts: the ant ('Fourmis'), the hedgehog ('Che cos'è la poesia?'), the silkworm ('Un ver à soie'), the spider, bee and serpents ('Freud et la scène de l'écriture' and 'La mythologie blanche'), wolves ('Fors'), various horses (Éperons, 'Parergon', Glas) and asses (multiple places in reference to Nietzsche's Zarathustra), the mole (Spectres de Marx), the hare and the swan (Politiques de l'amitié), the HMV dog (Otobiographies),

\footnotetext{
${ }^{1}$ Jacques Derrida, L'animal que donc je suis, ed. Marie-Louise Mallet (Paris: Galilée, 2006); The Animal That Therefore I Am, trans. David Wills (New York: Fordham University Press, 2008), 60/37; hereafter $A S$ with page references in the text.
} 
the swallow, shrimp and oyster (Signéponge) not to mention all the birds and fish, I could go on...

But what pricked up my all-too-human ears was a remarkable passage later in L'animal que donc je suis, where - with characteristic homonymic play - he suggests that the question of what would be proper to the animal and the possibility of reframing such a question is a matter of aurality. That is, the question of the animal is posed as a question of the ear. Derrida uses the word clé (key) understood in the double sense of that which keeps something secure and the musical meaning of tonality, which is itself a form of security. Instead of a key that could unlock and thereby liberate the animal from its anthropocentric, humanist confinement, Derrida wants a musical modulation, almost as if this were one of those crystalline, mosaic constructions in Schubert where one suddenly shifts flatwards.

Je voudrais seulement indiquer une tonalité, une hauteur des notes qui changent toute une portée. Comment changer la portée de telles questions sur l'être de ce qui serait proprement animal ? Comment, en quelque sorte, mettre un bémol à la clé de ces interrogations et changer la musique?

I wish only to indicate a tonality, some high notes that change the whole stave. How can the gamut of questions on the being of what would be proper to the animal be changed? How can a flat, as it were, be introduced in the key of this questioning to tone it down and change its tune? $(A S, 92 / 63)$

Why these notes should enter in a high register is unclear. What is specified quite unmistakably, though, is that this attunement to the animal must avoid the twin dangers of what Derrida in 'Economimesis' - in another, this time quasi-homophonic, pun calls 'exemplorality'. ${ }^{2}$ For Derrida the metaphysical border between man and the animal is bound up with the eating and with the tropes of cannibalism that he explores apropos of Hegel in Glas, published in 1974, and then in the seminar of 1990-91 devoted to 'Rhétorique du cannibalisme'. Specifically, the privilege that the metaphysical tradition awards to humanity hinges on 'the sacrifice and devouring of animals'. ${ }^{3}$ It is a matter of interiorizing or introjecting the animal-other in the psychoanalytic sense under examination in Derrida's foreword to Nicolas Abraham and Maria Torok's Cryptonymie. Le verbier de l'homme aux loups enigmatically entitled with the homophone 'Fors' - the same figure of taking into the body that we find in the figure of the Eucharist and adopted by the tradition of metaphysics as thematized in Glas. Even Martin Heidegger's ontological difference, for instance, marks the boundary between beings that can be assimilated and Being which cannot - which is to say between what can and cannot be eaten according to a persistent oral metaphor. ${ }^{4}$ To this extent, the entire history of metaphysics is a carnophallogocentrism.

This digestion of the animal is haunted, though, by the possibility of indigestion to the point of vomiting in what at first blush appears to be a radical exteriorization of the interior, turned inside out. If eating is a metonymy for introjection, which for Abraham

\footnotetext{
2 Jacques Derrida, 'Economimesis', in Sylvaine Agacinski et al., Mimesis des articulations (Paris: Aubier-Flammarion: 1975), 73; 'Economimesis', trans. Richard Klein, Diacritics 11.3 (1981): 13.

${ }^{3}$ Daniel Birnbaum and Anders Olsson, 'An Interview with Jacques Derrida on the Limits of Digestion', e-flux journal 2 (January 2009); available at https:/www.e-flux.com/journal/02/68495/an-interview-withjacques-derrida-on-the-limits-of-digestion/ [accessed 12 September 2021].

${ }^{4}$ Birnbaum and Olsson. See also Martin Heidegger, Sein und Zeit, $12^{\text {th }}$ ed. (Tübingen: Max Niemeyer, 1972); Being and Time, trans. John Macquarrie and Edward Robinson (New York: Harper \& Row, 1962).
} 
and Torok consists in a complete assimilation and integration of the lost object into the self and is thus said to constitute healthy mourning, in the fantasy of what they call incorporation 'il le mange (par la bouche ou autrement) pour ne pas l'introjecter, pour le vomir, pourrait-on dire, au-dedans, dans la poche d'une kyste [it involves eating the object (through the mouth or otherwise) in order not to introject it, in order to vomit it, in a way, into the inside, into the pocket of a cyst ${ }^{5}$ - thrown up so as to keep the voice of the other set apart. But Derrida questions whether this distinction can be upheld. He wonders on the contrary whether incorporation, instead of being pathological, were in fact to describe the impossibility for any interiorization to completely absorb the other. As Werner Hamacher observes in his famed study of the motifs of incorporation and eating in Hegel, the other - 'le vomi du système [the system's vomit]', as Derrida puts it in Glas, is spat out precisely in order to make it more digestible. ${ }^{6}$ And yet Hamacher hypothesizes that there is always an excess of nauseous disgust over ingestion that arises from a certain dispersal, or what I have described as a shattering, ${ }^{7}$ of the oral function into various orifices and channels of excretion, human and non-human.

This cycle, however, is not exclusively oral but discloses the phantasmic sovereignty of the entire mouth-ear circuit that appears to guarantee self-presence via the $s$ 'entendre parler (hearing-oneself-speak). In a passage worth quoting at length in the first year of the final seminar on La bete et le souverain, Derrida connects listening to the voice, orality to aurality (homophone!), in the guise of a beastly vociferation:

La souveraineté serait-elle dévoratrice ? Sa force, son pouvoir, sa plus grande force, sa puissance absolue serait-elle, par essence et toujours, en dernière instance, puissance de dévoration (appropriation par la bouche, les dents, la langue, compulsion à la morsure, à l'engloutissement de l'autre en soi, pour le mettre à mort ou en faire son deuil) ? Mais ce qui transite par la dévoration intériorisante, c'est-à-dire par l'oralité, par la bouche, la gueule, les dents, le gosier, la glotte et la langue - qui sont aussi des lieux du cri et de la parole, du langage -, cela même peut aussi habiter cet autre lieu du visage ou de la face que sont les oreilles, les attributs auriculaires, les formes visibles, donc audio-visuelle de ce qui permet non seulement de parler, mais d'entendre et d'écouter. "Grand-mère, comme tu as de grandes oreilles », dit-elle au loup. Le lieu de la dévoration, c'est aussi le lieu de ce qui porte la voix, c'est le topos du porte-voix - en un mot, le lieu de la vocifération. [...] L'une, la vocifération, extériorise ce qui se mange, dévore ou intériorise l'autre, et, inversement ou simultanément, la dévoration intériorise ce qui s'extériorise ou se profère. Et s'agissant de dévorer, de proférer, de manger, de parler et donc d'écouter et d'obéir en recevant au-dedans par les oreilles, s'agissant de la bête et du souverain, je vous laisse rêver aux oreilles d'âne du roi Midas qu'Apollon lui infligea parce qu'il lui avait préféré son adversaire dans une joute musicale. L'âne passe injustement pour la plus bête des bêtes.

Might sovereignty be devouring? Might its force, its power, its greatest force, its absolute potency be, in essence and always in the last instance, a power of devourment (mouth, teeth,

\footnotetext{
5 Jacques Derrida, 'Fors. Les mots anglés de Nicolas Abraham et Maria Torok', foreword to Nicolas Braham and Maria Torok, Cryptonymie: Le verbier de l'homme aux loups (Paris: Éditions AubierFlammarion, 1976); 'Fors: The Anglish Words of Nicolas Abraham and Maria Torok', trans. Barbara Johnson, in The Wolf Man's Magic Word, trans. Nicholas Rand (Minneapolis, MN: University of Minnesota Press, 1986), 56/xxxviii.

6 Jacques Derrida, Glas (Paris: Galilée, 1974); Clang, trans. Geoffrey Bennington and David Wills (Minneapolis, MN and London: University of Minnesota Press, 2020), 183a/183a. Werner Hamacher, Pleroma - Reading in Hegel, trans. Nicholas Walker and Simon Jarvis (Stanford: Stanford University Press, 1998), 251-2, 257.

${ }^{7}$ Naomi Waltham-Smith, Shattering Biopolitics: Militant Listening and the Sound of Life (New York: Fordham University Press, 2021).
} 
tongue, violent rush to bite, engulf, swallow the other, to take the other into oneself too, to kill it or mourn it)? But what goes via interiorizing devourment, i.e. via orality, via the mouth, the maw, teeth, throat, glottis, and tongue - which are also the sites of cry and speech, of language - that very thing can also inhabit that other site of the visage or the face, i.e. the ears, the auricular attributes, the visible and therefore audiovisual forms of what allows one not only to speak but also to hear and listen. 'Grandmother, what big ears you have', she says to the wolf. The place of devourment is also the place of what carries the voice, the topos of the porte-voix [megaphone, literally 'voice-carrier'], in a word, the place of vociferation. [...] The one, vociferation, exteriorizes what is eaten, devoured, or interiorized: the other, conversely or simultaneously, i.e. devourment interiorizes what is exteriorized or proffered. And on this subject of devouring, proffering, eating, speaking, and therefore listening, of obeying in receiving within through the cars, on the subject of the beast and the sovereign, I leave you to muse on the ass's ears of King Midas that Apollo inflicted on him because he had preferred his rival in a musical cum petition. The ass is thought, unfairly, to be the most stupid of beasts. ${ }^{8}$

The ear, then, is not only another orifice by which the other is interiorized but also what carries the voice over a distance and hence what spaces it out, disseminating and shattering it. Whereas devouring consumes the vomit that appears to be outside, showing that exteriorization to be but a moment necessary for incorporation, the ear's vociferation, figured as a megaphone, reveals that what appears to come from within, the voice, is in fact always already from the outset marked by dispersal, differentiation, technological prostheticity. The voice is never mine insofar as it is heard, and similarly, listening never my own insofar as it is overheard, as Peter Szendy elegantly demonstrates $^{9}$ - which is why listening always comes from the ear of the other.

In this passage, moreover, it is not so much a question of eating the animal as it is of devouring in a fashion that turns out to be beastly, thus deconstructing the fictional opposition between beast and sovereign, between animal noises and rational speech, upon which the privilege of the human rests. Beyond what the animal might sound like with a change of tune, with that modulation away from an anthropocentric tonality, what is at stake here is also a new kind of listening - one that is less about unlocking unheard secrets buried in inner crypts than it is about changing key by way of a chromatic inflection. The culmination of this passage with its reference to King Midas's ass's ears, an animal supposedly beset by an excess of betise, suggests that this reattunement of listening will involve something of an intensification or exacerbation of bestiality.

I want to park this thought for a moment and return to the passage in L'animal que donc je suis that we were tracking - stealthy as a wolf, à pas de loup, as the opening of the final seminar has it $^{10}$ - this passage we read where Derrida is dreaming of listening in such a way that would avoid both the Scylla of pure devouring and the Charybdis of absolute vomiting.

Comment faire entendre ici une langue ou une musique inouïe, assez inhumaine en quelque sorte, et non pas pour me faire ici le représentent ou l'émancipateur d'une animalité oubliée, ignorée, méconnue, persécutée, chasée, pêchée, sacrifiée, asservie, élevée, parquée, hormonisée, transgénétisée, exploitée, consommée, mangée, domestiquée, mais pour me faire

\footnotetext{
${ }^{8}$ Jacques Derrida, Séminaire La bête et le souverain, Volume I (2001-2002), ed. Michael Lisse, MarieLouise Mallet, and Ginette Michaud (Paris: Galilée, 2008); The Beast and the Sovereign, Volume I, trans. Geoffrey Bennington (Chicago and London: University of Chicago Press, 2009), 46/23.

${ }^{9}$ Peter Szendy, Sur écoute. Esthétique de l'espionnage (Paris: Minuit, 2007); All Ears: The Aesthetics of Espionage, trans. Roland Végső (New York: Fordham University Press, 2016).

${ }^{10}$ Derrida, La bête et le souverain I, 19/1ff.
} 
entendre dans une langue qui soit une langue, certes, et non de ces cris inarticulés, bruits, rugissements, aboiements, miaulements, pépiements insignifiants que tant d'hommes attribuent à l'animal, une langue enfin dont les mots, les concepts, le chant, l'accent soient assez étrangers à tout ce qui, dans toutes les langues humaines, aura hébergé tant de bêtises sur ledit animal?

How to have heard here a language or unheard-of music, somewhat inhuman in a way, yet not so as to make myself the representative or emancipator of an animality that is forgotten, ignored, misunderstood, persecuted, hunted, fished, sacrificed, subjugated, raised, corralled, hormonized, transgenetized, exploited, consumed, eaten, domesticated; rather, to have myself heard in a language that is a language, of course, and not those inarticulate cries or insignificant noises, howling, barking, meowing, chirping, that so many humans attribute to the animal, a language whose words, concepts, singing, and accent can finally manage to be foreign enough to everything that, in all human languages, will have harbored so many asinanities concerning the so-called animal. ( $A S, 92-93 / 63)$

Derrida goes on to note, anticipating the argument of the last seminar, that bettise is properly a human quality, for it makes no sense to speak of the betise or bestiality of the animal, which would hence be nothing but an anthropomorphism. He then continues:

Bref, je rêvais d'inventer une grammaire et une musique inouïes pour faire une scène qui ne soit ni humaine, ni divine, ni animale, en vue de dénoncer tous les discours sur ledit animal, toutes les logiques ou axiomatiques anthropo-théomorphiques ou anthropothéocentriques, la philosophie, la religion, la politique, le droit, l'éthique, en vue d'y reconnaître des stratégies animales, justement, au sens humain du mot, des stratagèmes, des ruses et des machines de guerre, des manœuvres de défense ou d'attaque, des opérations de chasse, de prédation ou de séduction, voire d'extermination dans une impitoyable lutte entre des espèces supposées.

In short, I was dreaming of inventing an unheard-of grammar and music in order to create a scene that was neither human, nor divine, nor animal, with a view to denouncing all discourses on the so-called animal, all the anthropo-theomorphic or anthropo-theocentric logics and axiomatics, philosophy, religion, politics, law, ethics, with a view to recognizing in them animal strategies, precisely, in the human sense of the term, stratagems, ruses, and war machines, defensive or offensive maneuvers, search operations, predatory, seductive, indeed exterminatory operations as part of a pitiless struggle between what are presumed to be species. $(A S, 93 / 63-4)$

The task of this reattuned listening would be to avoid making the listener the representative or emancipator of an animality that is subordinated to, sacrificed by, or excluded by the human and to hear animals as neither completely innocent nor absolutely, murderously savage. This unheard-of music would instead entail the deconstruction of the opposition between human and animal upon which an anthropocentric humanism rests. In a similar way to how resistances of psychoanalyses do not, for Derrida, demand disentangling by the ear of the analyst, as if the truth of the unconscious could thus be revealed, but instead call for re- and over-entangling, ${ }^{11}$ the change of tune does not require so much unbinding the animal from the human as finding new intertwinements. It is less a matter of cutting off than of more knotted connections. Which is why Derrida will complicate the relation between sovereign and beast by finding the former, epitomized by King Midas with his ass's ears, to be the

11 Jacques Derrida, Résistances de la psychanalyse (Paris: Galilée, 1996); Resistances of Psychoanalysis, trans. Peggy Kamuf, Pascale-Anne Brault, and Michael Naas (Stanford, CA: Stanford University Press, 1998), 34/20. 
most beastly of beasts (la plus bête des bêtes). Moreover, it is precisely those human discourses about the animal that mark that boundary that are revealed to be the most beastly, the most predatory and deadly, in their ruses - hence the characterization of human speech as the devouring, biting maw and the recollection of the grandmother's lupine ears in Little Red Riding Hood.

What is most interesting to me is the possibility that sovereignty be deconstructed less by its undoing than by the exacerbation or intensification of its constitutively beastly stratagems as if the most beastly, this hyper-betise, were a counterpart to the hyper-sovereignty of which Derrida speaks in the second year of the seminar. And it is to Hélène Cixous's writing that we might turn to find such a piling up of animality amid reflections upon the bonds that this animal life entails. But it isn't only animal life that fascinates Cixous, but also non-human modalities of living that become inextricably bound up with animals. In H. C. pour la vie, c'est à dire... Derrida observes that there are so many telephones in Cixous's writings that the theme could warrant six hundred dissertations, but he also is led to wonder if there are more telephones or more animals, observing their interchangeability, the possibility of replacing various non-human, even mechanistic forms of life with one another in a generalized prostheticity of life or, better, as we shall see, life as generalized prostheticity, something not unrelated to what David Wills has explored under the category of 'inanimation'. ${ }^{2} \mathrm{He}$ answers his question: 'Les animaux sont les téléphones et parfois réciproquiement, et ils se multiplient [Animals are telephones and sometimes the other way around, and they multiply'], he quips with a Cixousian pun, 'dans leur prolifaunie de toutes les métamorphones animales, humaines et divines [in the prolifauny of all their animal, human, and divine metamorphoses]' (HC, 90/102).

This prolifauny of animal substitutions in Cixous's writings - cats, dogs, wolves, lions, ants, bees, worms, swans, other birds, elephants, the mythical half-human, halfanimal faun, even the inorganic telephone - proceeds by way of what Derrida describes not simply as an art of replacement but even more specifically as a differential 'l'économéto-homonymie [econo-meto-homonymy of living life]' $(H C, 100 / 114)$ that 'remplace à l'instant, sur l'heure, sans attendre, un nom, une marque, l'adresse ou le sense d'un phonème, d'une syllable ou d'un graphème, etc. [replaces a noun, a mark, the address, or the meaning of a phoneme, of a syllable, or of a grapheme, etc., instantly, at once, without delay]' (HC, 67/73). Derrida wants to stress the iterability of names, but he also recognizes the aural component - the homophony - at work in Cixous's proliferation of animal and inorganic life which allows an elephant to turn into a telephant (un petit (t)éléphant) and the hybrid faun into a telefaune. In a particularly virtuosic passage in Ananke that instantiates the resistance to translation of which it in part speaks, Cixous simultaneously performs and reflects upon - and thus re-marks - the implication of the sonorous in this telephonic replaceability of life.

un néléfan, un téléphant, un zéléphan, un éléphone, un tel est faune, au téléfaune, un tel est faux, cet éléphone est peut-être fictif, un téléfaune est peut-être toujours fictif d'ailleurs ne vaut-il pas mieux raccrocher? [...] ôter les faunes, couper les faux nœuds [...] la sonnerie d'un olifant [...]

\footnotetext{
${ }^{12}$ Jacques Derrida, H. C. pour la vie, c'est-à-dire... (Paris: Galilée, 2002); H. C. for Life, That Is to Say ..., trans., with additional notes, by Laurent Milesi and Stefan Herbrechter (Stanford, CA: Stanford University Press, 2006), 90/102; hereafter $H C$ with page references in the text. David Wills, Inanimation: Theories of Inorganic Life (Minneapolis, MN and London: University of Minnesota Press, 2016).
} 
a Dumbo-elephant, a telephant, a zele-phant [zealous], an elephone, such-a-faun, on the telefaun, ever-so-faux, this elephone is perhaps fictitious, a telefaun is perhaps always fictitious, besides is it not better to hang up? [...] block the fauns, cut off phoney connections $[\ldots]$ the ringing horn of an olifant $[\ldots]^{13}$

It is no coincidence, I would suggest, that immediately having dreamt of the un-heard music that would change the tune of the animal, Derrida invokes his own 'jeu à la fois innocent et pervers de l'homonyme [innocent and the same time perverse game of homonymy]' $(A S, 94 / 64)$ in L'animal que donc je suis with the play on je suis meaning both I am and I follow.

I am, of course, not the first to point to the untranslatable homophony and sonorous effects of Cixous's prose. One of her foremost translators into English, Peggy Kamuf, has observed: 'One has to look not just for what words and sentences are meaning [...] But one has also, for example, to break down words and look for the repetition of phonemes and sounds, according to a poetic principle. ${ }^{, 14}$

Lynn Turner, moreover, has already brilliantly analysed the threads that weave together the theme of the telephone and Cixous's expanding menagerie with the aural dimension of her writing, enjoining us to move away from linguisticism by listening to the sounding poetics of her language and inventing her own quasi-homophone, 'telefoam',to suggest that 'there is the chance of something quite different being sounded in Cixous's writing' whose 'words lap against your ears' like waves on the shore. ${ }^{15}$ Extending this thought in the direction of the homonymic chain that Derrida in Un ver à soie describes as an infinite 'tresse de phonèmes [braid of phonemes]', ${ }^{16}$ I want to prostheticize Turner's thinking along this braid or animal silvery thread, woven by the silkworm, weaving over, over-threading, re-braiding her text. Derrida remarks that 'd'abord elle se donne à entendre, elle se noue hors de la vue [primarily it gives itself to be heard, it is knotted out of sight]' and that, like the 'trame [warp]' of the text, it remains forever 'intraduisible [untranslatable]'. What is untranslatable in homophony and homonymy, in this absolute idiomaticity I want to call, of course, homofaunie, is not something that can be gathered into a single, unifying fundamental tone, as Heidegger is wont to do in his reading of Trakl for instance, but is, as Derrida describes his altogether different reading method in Geschlecht $I I I,{ }^{17}$ the leaps and bounds by which the metonymic thread binds one substitute to another without original, the event of replacing at great telegraphic speed on the spot - that is, the generalized fetishism that makes up the texture of ambitious and highly virtuosic literary endeavour in which that concept is posed, that is, Glas. ${ }^{18}$

\footnotetext{
${ }^{13}$ Hélène Cixous, Anankè (Paris: des Femmes, 1979), 172; trans. mine. See Laurent Milesi's discussion of this passage in 'Cixanalyses - Toward a Reading of Anankè', Paragraph 36.2 (2013): 297-300.

${ }^{14}$ Peggy Kamuf with Dawne McCance, 'Crossings: An Interview with Peggy Kamuf', Mosaic: An Interdisciplinary Critical Journal 42.2 (2009): 237.

${ }^{15}$ Lynn Turner, 'Telefoam: Species on the Shores of Cixous and Derrida', European Journal of English Studies 18.2 (2014): 160.

${ }^{16}$ Jacques Derrida, 'Un ver à soie. Points de vue piqués sur l'autre voile', in Hélène Cixous and Jacques Derrida, Voiles (Paris: Galilée, 1998); 'A Silkworm of One's Own: Points of View Stitched on the Other Veil', in Veils, trans. Geoffrey Bennington (Stanford, CA: Stanford University Press, 2002), 55/56, hereafter $V S$ with page references in the text.

17 Jacques Derrida, Geschlecht III. Sexe, race, nation, humanité, ed. Geoffrey Bennington, Katie Chenoweth, and Rodrigo Therezo. (Paris: Seuil, 2018); Geschlecht III: Sex, Race, Nation, Humanity, trans. Katie Chenoweth and Rodrigo Therezo (Chicago: University of Chicago Press, 2020).

${ }^{18}$ Derrida, Glas, 234-36ai.
} 
Returning to Cixous, if the telephone wire is a 'lien vital [vital bond]' (HC, 73/81 et passim) like the umbilical cord that holds onto, secures, saves life, it is also as precarious as the funambulist's wire in Cixous's characterization in $O R .{ }^{19}$

Rien ne serait plus niais (mais toute la résistance transférentielle que rencontre l'œuvre d'Hélène Cixous est étourdie dans cette niaiserie) que de lire ces inventions verbales et poétiques (téléphantasmes, par exemple) comme de simples jeux de mots dont elle aurait le génie ou la facilité - ou même comme de simples phantasmes. Chaque fois il y va, dans la production et selon la nécessité [...] d'un événement de langue, d'une analyse pensante de ce qui lie et délie dans le vivre même du vivant, donc dans l'animalité de l'animal, la vitesse en tant qu'elle annule la distance, le phénomène télé, mais du même coup lie et élie l'apparaître du phénomène, le phainesthai, en tant qu'il est indissociable du phantasmea, c'est à dire à la fois du rêve et du fantôme spectral, de la revenance, ce que veut dire aussi phantamsa.

Nothing would be more inane - but all the transferential resistance that is met by Hélène Cixous's work spins dizzily in these inanities - than to read these verbal and poetic inventions (telephantasms, for example) as simple puns she would have the knack for and which would come easily to her - or even as simple phantasms. Each time, what is at stake, in the production and according to the necessity [...] of a language event, is a thoughtful analysis of what binds and unbinds in the very living of the living, therefore in the animality of the animal, speed insofar as it cancels distance, the tele phenomenon, bur at the same time binds and unbinds the appearing of the phenomenon, the phainesthai, insofar as it is indissociable from the phantasma, that is to say, both from the dream and the spectral phantom, of revenance, which phantasma also means. (HC, 90-91/102-103)

Accordingly, the listening that would be attuned to the animality of the animal and to the life of the living, of all that lives, to that metaphorical, prosthetic, inanimate life of the trace that Derrida many years earlier in L'écriture et la différence had dubbed 'une animalité de la lettre [an animality of the letter] ${ }^{20}$ - listens for what binds and unbinds in telehomofaunie. It is to the mighty sur-puissance of Life as Derrida put it then - to what appears in Cixous's writing under the guise of the mighty subjunctive puisse, the would-that-I-might! - that she lends her ear. In Anankè, wondering what the relation is between strands of hair and elephants, Cixous reflects on her own enthusiasm for 'le long de chaînes métonymiques ou matérialisées sous forme de fil, de rubans, de mèches, de boucles, et autre attaches extensibles, élastique et d'une solidité d'autant plus grande qu'elle était assurée d'une complicité affective [the metonymic chains or the ones materialized in the guise of a wire, ribbons, strands, buckles, and other fastening devices, elastic and all the greater for being assured by an affective complicity]' - these wispy wires by which she is attached to her elephantasms, at once animal and spectral. ${ }^{21}$

To trace this interweaving of animal and non-animal or technological life one can also go back to 'Fourmis', a lecture Derrida delivered in 1990, directly after Cixous's own contribution, for a colloquium devoted to Lectures de la différence sexuelle, and which addresses the theme of the idiom. Moreover, the untranslatable expression in question is given to Derrida when Cixous recounts a dream over the telephone: le fourmi, meaning 'ant', except that fourmi is in fact in French a feminine noun and never properly takes a masculine article. This gifted word, the betrayed secret of the idiom - a

\footnotetext{
${ }^{19}$ Hélène Cixous, OR, les lettres de mon père (Paris: des Femmes, 1997), 21.

20 Jacques Derrida, L'écriture et la différence (Paris: Seuil, 1967); Writing and Difference, trans. Alan Bass (Chicago and London: University of Chicago Press, 1978), 108/72.

${ }^{21}$ Cixous, Anankè, 171; trans. mine.
} 
play here on donner le mot - prompts Derrida to dream up a series of homonymic and quasi-homophonic idiomatic expressions, but it also motivates the observation that sexual difference is something 'à lire et non à voir [to be [...] read and not seen]. ${ }^{22}$ The sex of this tiny black creature, which belongs to the order of winged insects or hymenoptera but which may lose one or both of its wings, is rather hard to see. Moreover, its masculinization in Cixous's dream, Derrida argues, removes it from vision, consigning it to the obscurity of blindness, but in this way it promises itself to reading. Sexual difference as such remains 'problématique, mobile, non assurée, elle passe, elle est de passage, elle passe de l'un à l'autre, par l'un et l'autre, de l'une à l'autre comme une fourmi, un fourmi de rêve [problematic, mobile, uncertain, it goes, it is in passage, it passes from one to the other like une fourmi, un fourmi of a dream]', and resuming after this lengthy parenthesis on how 'tous les mots sont des fourmis, [all words are ants]', 'le mot insecte, donc, tel qu'on l'entend sans le voir, comme au telephone, il fourmille de sens [the word insect, therefore, as it is heard without being seen, as on the telephone, teems with meanings.' $(F, 74-5 / 20-1)$

The reading of sexual difference - double genitive - is, on this argument, caught up in aurality, specifically in the telephony via which so much of Derrida's relationship with Cixous was conducted. Derrida swiftly associates telephony, and especially the mobile, wireless phone, with blindness. At the same time, he links the genealogical aspect of sexual difference or Geschlecht to the coup de télephone, which must be understood now, far from being the lineage of a bloodline or the maternal umbilical line, as an 'improbable' and much more chancy multiplication. We may recall form Derrida's La carte postale that a postcard may not arrive at its destination; similarly, a phone call can always be misdirected or the connection broken:

Laissons-là le fourmi fourmiller après avoir commis l'insecte. Laissons-le se multiplier selon des généalogies improbables, avec ou sans fils. Rêve portatif. Hélène m'a raconté ce rêve en me tenant au bout du fil sans fils, à savoir au téléphone, le téléphone aujourd'hui : on peut appeler ou écouter de n'importe où. Voilà, nous avons déjà le téléphone et l'aveuglement.

Let us leave le fourmi to teem after having committed insect. Leave it to multiply according to improbable genealogies with or without wires. Portable dream. Hélène told me this dream while holding me at the end of the line without line, which is to say on the telephone, today's telephone: one can call and listen from anywhere. There, we already have the telephone and blindness. $(F, 94-35)$

Derrida goes on to assert that the untranslatable idiom, moreover, exists only telephonically, which is to say never seen, only to be heard and to be read. The question of the animal then multiplies with the appearance of a common figure in Cixous's characterizations of writing, namely the metaphor of the wing-flap appears. Referencing the pun he made years earlier in 'La parole soufflée" ${ }^{23}$ and which Cixous for her part recalls many times over, Derrida recounts how he steals the word that she whispers to him, souffler meaning to utter under one's breath and also to spirit away, to pinch - and we might also recall in this context the expression ne pas souffler mot, not to breathe a word, as counterpart to donner le mot. Cixous's whispering of this stolen word, now

\footnotetext{
${ }^{22}$ Jacques Derrida, 'Fourmis', in Lectures de la différence sexuelle, ed. Mara Negrón (Paris: des Femmes, 1994; 'Ants', trans. Eric Prenowitz, Oxford Literary Review 24.1 (2002): 75/21, hereafter $F$ with page references in the text.

${ }^{23}$ Jacques Derrida, 'La parole soufflée', in L'écriture et la différence, 253-92/170-95.
} 
with a play on voler, transmutes into the 'sound of wings and flight of a word [bruit d'aile et vol d'un mot]':

Le téléphone est d'ailleurs l'aveuglement; et le fourmi, mot que je suis toujours tenté d'écrire, spontanément, au singulier avec un $s$, je ne sais pas pourquoi, c'est une chose téléphonique, elle est prise dans un halo [«allô, c'est moi »] puisqu'on entend sans voir et qu'au fond le fourmi n'existe pas hors de quelque appel téléphonique ; on n'a jamais vu ça, ni la chose ni même le mot écrit, pas encore en tout cas, et tout ce que je voulais faire, c'est peut-être donner un corps d'écriture publique au fourmi qu'Hélène m'avait seulement soufflé au téléphone : bruit d'aile et vol d'un mot. Je lui ai soufflé le mot qu'elle ma soufflé, je le lui ai volé, non, je le lui ai emprunté $[\ldots]$

The telephone is blindness, by the way; and le fourmi, a word that I am always tempted spontaneously to write in the singular with an $s$, I know not why, is a telephonic thing, it is taken up in a halo ['hello, it's me'] because one hears without seeing and in the end le fourmi does not exist outside of some telephonic call; it has never been seen, neither the thing nor even the written word, not yet in any case, and all I wanted to do was perhaps to give a body of public writing to le fourmi that Hélène had only whispered to me on the telephone: sound of wings and flight [ $\mathrm{vol}]$ of a word. I whispered to her the word she whispered to me, I stole it from her, no, I borrowed it from her $[\ldots](F, 94-5 / 35)$

And later this flight, which now marks the passage from seeing to reading and is explicitly characterized as an absolute leap flying 'avec ou sans aile [with or without wings]' over a chasm, presupposing an experience of blindness - this flight displaces orality with aurality in what Derrida calls 'le moment aboculaire [the abocular moment]':

On ne passe jamais de voir à lire sans un saut absolu. Nous ne dirons pas que c'est un pari mais, comme la différence entre voir et ne pas voir, il passe au-dessus d'un abîme sans fond. Avec ou sans aile, on ne doit jamais savoir, il vole au-dessus d'un gouffre quasiment infini [...] d'une part, il faudrait dire que nous interprétons la différence sexuelle au sens où nous la lisons, c'est-à-dire sans la voir, seulement à en témoigner au-delà du fait anatomique, de la preuve par l'état civil, de toute la grille des critères dits objectifs de l'identification sexuelle donc en passant de voir à lire; d'autre part, nous devrions rappeler le saut infini qui, passant de voir à lire, suppose une telle expérience, une telle endurance de l'aveuglement, une telle épreuve du témoignage, là où il passe par le moment aboculaire (avec ou sans le supplément d'une antenne téléphonique $[\ldots]$ )

One never goes from seeing to reading without an absolute leap. We will not say that it is a wager, but like the difference between seeing and not seeing, it passes over a bottomless abyss. With or without wings, we must never know, it flies over a quasi-infinite chasm [...] on the one hand, it must be said that we are interpreting sexual difference in the sense that we are reading it, which is to say without seeing it, only so as to bear witness to it beyond the anatomical fact, beyond the proof of the civil status, beyond every system of so-called objective criteria of sexual identification - thus by passing from seeing to reading; on the other hand, we must remember the absolute leap that, in passing from seeing to reading, presupposes such an experience, such an endurance of blindness, such a test of witnessing, where it involves the abocular moment (with or without the supplement of a telephonic antenna [...]) (95-6/36)

(The reference to the telephonic antenna is to Maeterlinck's La vie des fourmis which notes that ant's vision is so weak that their eyes must be supplemented by antennae which scientists have more recently shown also operate as a two-way communication system.) The generalization of life's difference beyond binaries, male and female, human and animal, organic and inorganic, thus depends upon an aural prosthesis - or, more precisely, on aurality as prostheticity. 
The theme of blindness and secrecy pervades Derrida and Cixous's exchanges. In Voiles, the theme of aurality, as the question of untranslatable, idiomatic homonymy, is especially prominent and is again associated with blindness, mystery and winged animals. If le fourmi is 'insecte hyménoptere, donc, insecte à aile, insecte à hymen, à aile voilée, à aile en forme de voile [the hymenoptera insect, therefore, winged insect hymened insect, with veiled wings, with wings like veils]' $(F, 74 / 20)$, in Derrida's response to Cixous's 'Savoir', it is another winged insect that takes flight in its unveiling: the silkworm, awakened from its cocoon. This cocoon is spun from an endless 'écho en chaîne [chain of echoes]'; this infinite 'tresse de phonèmes [...] elle se noue hors de la vue, devenant ainsi chose de la myopie ou de la cécité [braid of phonemes [...] knotted out of sight, becoming thus a thing of myopia and blindness.]' $(V S, 55 / 56)$ The coup d'aile or wing-flap comes in a passage on the pure audibility of the idiom, invisible on the page and untranslatable, which gives rise in French to a chain of homonymic and homophonic vocables, as Derrida is wont to call them, words or particles insofar as they are sounded. This sentence in suspense 'remue les ailes à la naissance, comme le papillon du ver à soie, au-dessus du cocon, à savoir du poème [flaps its wings at birth, like the silkworm butterfly, above the cocoon, that is, the poem].' $(V S, 38 / 35-6)$

En un mot comme en tant de mots, et certains paraissent visibles, d'autres audibles, dans un écheveau de bris de mots de toute sorte, un nom, le savoir, un verbe à l'infinitif, savoir, un pronom (démonstratif), ça, un adjectif (possessif), sa, des signes de ponctuation, des homonymes et apostrophes invisibles, $S^{\prime}$ 'avoir, tout cela devient ici, ici seulement, dans les phrases de ce texte-ci, le corps unique d'un mot inouï, plus ou moins qu'un mot, la grammaire d'un syntagme en expansion. Une phrase en suspens qui remue les ailes à la naissance, comme le papillon du ver à soie, au-dessus du cocon, à savoir du poème.

In a word as in so many words, and some of them appear to be visible, others audible, in a skein of shards of words of all sorts, a noun, le savoir, a verb in the infinitive, savoir, a (demonstrative) pronoun, ça, a (possessive) adjective $s a$, punctuation marks, invisible homonyms and apostrophes, S'avoir, all that becomes here, only here, in the sentences of this text here, the unique body of an unheard-of word, more or less than a word, the grammar of a syntagm in expansion. A sentence in suspense that flaps its wings at birth, like the silkworm butterfly, above the cocoon, that is, the poem.

The metaphor of woven shards, recalling Cixous's braids and wires, points intratextually to the fabric of the veil and outside the text to the co-articulation of cutting and weaving or lacing at work in the notion of stricture - on the one hand, to the shattered éclats of Glas and the mot brisé of Fors and on the other, to the various woven cloths and interlaced threads in La vérité en peinture and, thinking more politically, if this is not too much of a leap, to the poikilon, multi-coloured patchwork character of democracy that Geoff Bennington, responding to a reference to Plato in Voyous and even earlier in 'La pharmacie de Platon', has recently been elaborating. ${ }^{24}$ Thought together, these two metaphors - of taking off and of weaving - suggest a way of rethinking non-human tonalities of living.

\footnotetext{
${ }^{24}$ See Geoffrey Bennington, Scatter 2: Politics in Deconstruction (New York: Fordham University Press, 2021), especially 147ff. Derrida's references to the concept in Plato are in Voyous. Deux essais sur la raison (Paris: Galilée, 2003); Rogues: Two Essays on Reason, trans. Pascale-Anne Bault and Michael Naas (Stanford, CA: Stanford University Press, 2005), 48-9/26; and 'La pharmacie de Platon', in $L a$ dissémination (Paris: Seuil, 1972); 'Plato's Pharmacy', in Dissemination, trans. Barbara Johnson (Chicago and London: University of Chicago Press, 1981), 166-7/144-5.
} 
To Derrida's ears, Cixous's animating, resuscitating 'bons d'immortalité skips from bons to bonds with a 'd', to bondir and bon dire. He wants to make her bon mots re-sound as bounds to indicate a standing leap into immortality that takes time from time, outspeeding time, like the flap of a bird's wing with which Cixous's writing takes off. Far from being either a wilful mishearing or a psychoanalytic listening that solves or liberates the truth of the unconscious, the reattunement of Derrida's ears in L'animal que donc je suis, specifically the way in which his ear leaps up to a flat high on the stave, reties the escaping tone, pulling it back down with a chromatic dipping towards the ground, rather like the taking flight of the belimed bird figured in Glas as a metaphor for the act of reading. The aural reattunement that would change the tune of the animal is not, then, a question of letting the animal soar free and unalloyed high on the stave but precisely of alloying oneself in the chromatic mixture of homofaunie to the mighty power of animal life - which is also to say forming an alliance between human and animal not through the teleology of dominant-tonic relations but through multicoloured, motley, poikilon chromatic dispersal of aurality. (As an aside, we may note that this is one reason why the struggle against climate catastrophe and species extinction must take the form of a Green New Deal that would necessarily involve radical economic democratization.)

\section{As Derrida elaborates in H. C. pour la vie:}

Si l'interprétation suppose l'analyse, c'est à dire l'analuein de la déliaison qui dénoue, alors faire, au contraire, revient ici à lier, à se lier et à s'allier. À faire le contraire en même temps. À la mesure de ce texte, pour l'invention d'une critique comme poétique de la lecture, il ne peut s'agit que d'un acte d'écriture comme acte d'amour qui lie et lise, puisse lire en déliant les fils, tout en tressant une alliance dans l'analyse de la déliaison même.

If interpretation supposes analysis, that is to say, the analuein of the unbinding that unties, then to make or $d o$, on the contrary, comes down to binding, to binding oneself and allying oneself, to doing the contrary at the same time. Only an act of writing as an act of love that binds and reads - might read as it unbinds the threads, while weaving an alliance in the analysis or unbinding itself - can measure up to this text for the invention of a criticism as a poetics of reading. $(H C, 91-2 / 104)$

It is perhaps not Derrida himself but another of the woman's voices that he hears in the fabric of his texts, the voice of Anne Dufourmantelle that articulates best the risk that such a listening entails. Reflecting in De l'hospitalité on the experience of attuning to Derrida's speech, she says:

La première impression retirée de l'écoute du séminaire est d'entendre se dérouler une partition musicale qui rendrait audible le mouvement même de la pensée. Tout se passe comme si on assistait à une pensée pensante au moment même de son énonciation. Celui qui philosophe ainsi à voix haute ne déroule pas une trame lisse et univoque, il en expose les déchirures. Il laisse place à l'étonnement.

The first impression you draw from listening to the seminar is of hearing a musical score being played that makes the very movement of thinking audible. It is as if we were the audience for the thinking of a thought at the very moment of its utterance. Someone who philosophizes out 
loud in this way does not unwind a smooth, univocal thread; he shows the tears in it. He leaves room for astonishment. ${ }^{25}$

Neither completely bound nor unbound, the line neither absolutely connected nor cut off, the ear that changes the tune of the animal listens, as Dufourmantelle puts it elsewhere echoing Blanchot, 'par excès de douceur, la folie douce [with an excess of gentleness, gentle madness] ${ }^{26}$ - that ear listens - if I am permitted this homophonic play to sign off - to the undreamed-of as-tone-ishment of that flat high on the stave.

\section{Bibliography}

1. Birnbaum, Daniel and Anders Olsson. 'An Interview with Jacques Derrida on the Limits of Digestion'. e-flux journal 2 (January 2009). Available at https://www.eflux.com/journal/02/68495/an-interview-with-jacques-derrida-on-the-limits-of-digestion/. Accessed 12 September 2021.

2. Cixous, Hélène. Anankè. Paris: des Femmes, 1979.

3. Cixous, Hélène. OR, les lettres de mon père. Paris: des Femmes, 1997.

4. Derrida, Jacques. L'animal que donc je suis. Edited by Marie-Louise Mallet. Paris: Galilée, 2006. The Animal That Therefore I Am. Translated by David Wills. New York: Fordham University Press, 2008.

5. Derrida, Jacques. La carte postale de Socrate à Freud et au-delà. Paris: Aubier-Flammarion, 1980. The Post Card: From Socrates to Freud and Beyond. Translated by Alan Bass. Chicago: University of Chicago Press, 1980.

6. Derrida, Jacques. 'Che cos'è la poesia?' In Points: Interviews, 1974-1994. Edited by Elisabeth Weber. Translated by Peggy Kamuf. \& others. Stanford, CA: Stanford University Press, 1995, 288-99.

7. Derrida, Jacques. 'Economimesis'. In Sylviane Agacinski et al. Mimesis des articulations. Paris: Aubier-Flammarion: 1975, 57-93. 'Economimesis'. Translated by Richard Klein. Diacritics 11.3 (1981): 3-25.

8. Derrida, Jacques. L'écriture et la différence. Paris: Seuil, 1967. Writing and Difference. Translated by Alan Bass. Chicago: University of Chicago Press, 1978.

9. Derrida, Jacques. 'Fourmis'. In Lectures de la différence sexuelle. Edited by Mara Negrón. Paris: des Femmes, 1994, 69-102. 'Ants'. Translated by Eric Prenowitz. Oxford Literary Review 24.1 (2002): 17-42.

10.Derrida, Jacques. 'Fors. Les mots anglés de Nicolas Abraham et Maria Torok'. Foreword to Nicolas Abraham and Maria Torok. In Cryptonymie. Le verbier de l'homme aux loups. Paris: Aubier-Flammarion, 1976. 7-73. 'Fors: The Anglish Words of Nicolas Abraham and Maria Torok'. Translated by Barbara Johnson. In The Wolf Man's Magic Word. Translated by Nicholas Rand. Foreword by Jacques Derrida. Minneapolis, MN: University of Minnesota Press, 1986. xi-xlviii.

11.Derrida, Jacques. 'Freud et le scène de l'écriture'. In L'écriture et la différence. Paris: Seuil, 1967.196-231. 'Freud and the Scene of Writing'. In Writing and Difference. Translated by Alan Bass. Chicago: University of Chicago Press, 1978. 293-340.

\footnotetext{
25 Jacques Derrida and Anne Dufourmantelle, De l'hospitalité. Anne Dufourmantelle invite Jacques Derrida à répondre (Paris: Calmann-Lévy, 1997); Of Hospitality: Anne Dufourmantelle Invites Jacques Derrida to Respond, trans. Rachel Bowlby (Stanford, CA: Stanford University Press, 2000), 26-8/22-4.

26 Anne Dufourmantelle, La puissance de la douceur (Paris: Payots \& Rivages, 2013); Power of Gentleness, trans. Katherine Payne and Vincent Sallé, foreword by Catherine Malabou (New York: Fordham University Press, 2018), 110/78.
} 
12.Derrida, Jacques. Geschlecht III. Sexe, race, nation, humanité. Edited by Geoffrey Bennington, Katie Chenoweth, and Rodrigo Therezo. Paris: Seuil, 2018. Geschlecht III: Sex, Race, Nation, Humanity. Translated by Katie Chenoweth and Rodrigo Therezo. Chicago: and London: University of Chicago Press, 2020.

13.Derrida, Jacques. Glas. Paris: Galilée, 1974. Clang. Translation by Geoffrey Bennington and David Wills. Minneapolis, MN and London: University of Minnesota Press, 2020.

14.Derrida, Jacques. H. C. pour la vie, c'est-à-dire... Paris: Galilée, 2002. H. C. for Life, That Is to Say... Translated, with additional notes, by Laurent Milesi and Stefan Herbrechter. Stanford, CA: Stanford University Press, 2006.

15.Derrida, Jacques. 'La mythologie blanche'. In Marges - de la philosophie. Paris: Minuit, 1972. 249-324. 'White Mythology'. In Margins of Philosophy. Translated by Alan Bass. Chicago and London: University of Chicago Press, 1990, 207-71.

16.Derrida, Jacques. Otobiographies. L'enseignement de Nietzsche et la politique du nom propre. Paris: Galilée, 1984. 'Otobiographies'. Translated by Avital Ronell. In The Ear of the Other: Otobiography, Transference, Translation. Edited by Christie McDonald. New York: Schocken Books, 1985.

17.Derrida, Jacques. 'Parergon'. In La vérité en peinture. Paris: Flammarion, 1978. 23-168. 'Parergon'. In The Truth in Painting. Translated by Geoffrey Bennington and Ian McLeod. Chicago and London: University of Chicago Press, 1987. 15-147.

18.Derrida, Jacques. 'La pharmacie de Platon'. In La dissémination. Paris: Seuil, 1972. 71-197. 'Plato's Pharmacy'. In Dissemination. Translated by Barbara Johnson. Chicago and London: University of Chicago Press, 1981, 61-171.

19.Derrida, Jacques. Politiques de l'amitié. Paris: Galilée, 1994. The Politics of Friendship. Translated by George Collins. London and New York: Verso, 1997.

20.Derrida, Jacques. Résistances de la psychanalyse. Paris: Galilée, 1996. Resistances of Psychoanalysis. Translated by Peggy Kamuf, Pascale-Anne Brault, and Michael Naas. Stanford, CA: Stanford University Press, 1998.

21.Derrida, Jacques. 'Politiques de l'amitié. Rhétorique du cannibalisme'. Unpublished seminar, Archive-Derrida, IMEC, 219DRR/232/3, 1990-1991.

22.Derrida, Jacques. Séminaire La bête et le souverain, Volume I (2001-2002). Edited by Michel Lisse, Marie-Louise Mallet, and Ginette Michaud. Paris: Galilée, 2008. The Beast and the Sovereign, Volume I. Translated by Geoffrey Bennington. Chicago: University of Chicago Press, 2009.

23.Derrida, Jacques. Signéponge / Signsponge. Translated by Richard Rand. New York: Columbia University Press, 1984.

24.Derrida, Jacques. Spectres de Marx. L'État de la dette, le travail du deuil et la nouvelle Internationale. Paris: Galilée, 1993. Specters of Marx: The State of the Debt, the Work of Mourning and the New International. Translated by Peggy Kamuf. With an Introduction by Bernd Magnus and Stephen Cullenberg. New York: Routledge, 1994.

25.Derrida, Jacques. Spurs: Nietzsche's Styles / Éperons. Les styles de Nietzsche. Translated by Barbara Harlow. Chicago and London: University of Chicago Press, 1979.

26.Derrida, Jacques. 'Un ver à soie. Points de vue piqués sur l'autre voile'. In Hélène Cixous and Jacques Derrida. Voiles. Accompagné de six dessins d'Ernest Pignon-Ernest. Paris: Galilée, 1998, 23-85. 'A Silkworm of One's Own: Points of View Stitched on the Other Veil'. In Veils. With drawings by Ernest Pignon-Ernest. Translated by Geoffrey Bennington. Stanford, CA: Stanford University Press, 2002, 17-92.

27.Derrida, Jacques. La vérité en peinture. Paris: Flammarion, 1978. The Truth in Painting. Translated by Geoffrey Bennington and Ian McLeod. Chicago and London: University of Chicago Press, 1987.

28.Derrida, Jacques. Voyous. Deux essais sur la raison. Paris: Galilée, 2003. Rogues: Two Essays on Reason. Translated by Pascale-Anne Bault and Michael Naas. Stanford, CA: Stanford University Press, 2005. 
29.Derrida, Jacques and Anne Dufourmantelle. De l'hospitalité. Anne Dufourmantelle invite Jacques Derrida à répondre. Paris: Calmann-Lévy, 1997. Of Hospitality: Anne Dufourmantelle Invites Jacques Derrida to Respond. Translated by Rachel Bowlby. Stanford, CA: Stanford University Press, 2000.

30.Dufourmantelle, Anne. Puissance de la douceur. Paris: Payots \& Rivages, 2013. Power of Gentleness. Translated by Katherine Payne and Vincent Sallé. Foreword by Catherine Malabou. New York: Fordham University Press, 2018.

31.Hamacher, Werner. Pleroma - Reading in Hegel. Translated by Nicholas Walker and Simon Jarvis. Stanford: Stanford University Press, 1998.

32.Heidegger, Martin. Sein und Zeit. Twelfth Edition. Tübingen: Max Niemeyer, 1972. Being and Time. Translated by John Macquarrie and Edward Robinson. New York: Harper \& Row, 1962.

33.Kamuf, Peggy with Dawne McCance. 'Crossings: An Interview with Peggy Kamuf'. Mosaic: An Interdisciplinary Critical Journal 42.2 (2009): 1-17.

34.Milesi, Laurent. 'Cixanalyses - Toward a Reading of Anankè'. Paragraph 36.2 (2013): 286302.

35.Szendy, Peter. Sur écoute. Esthétique de l'espionnage. Paris: Minuit, 2007. All Ears: The Aesthetics of Espionage. Translated by Roland Végső. New York: Fordham University Press, 2016.

36.Turner, Lynn. 'Telefoam: Species on the Shores of Cixous and Derrida'. European Journal of English Studies 18.2 (2014): 158-71.

37. Waltham-Smith, Naomi. Shattering Biopolitics: Militant Listening and the Sound of Life. New York: Fordham University Press, 2021.

38.Wills, David. Inanimation: Theories of Inorganic Life. Minneapolis, MN and London: University of Minnesota Press, 2016.

\section{Homofaunie. Tonalități non-umane ale ascultării în operele lui Derrida și ale lui Cixous}

\section{Rezumat}

În L'animal que donc je suis, Jacques Derrida sugerează că problematica specifică animalităţii ar trebui ,să-şi schimbe tonul”. Citesc acest pasaj extraordinar, în care Derrida ne îndeamnă să ne folosim urechile pentru a percuta o ,,muzică neauzită” care nici nu emancipează non-umanul nici nu îl condamnă la un zgomot inarticular, în paralel cu un nexus al animalului, telefonie, și le cri de la littérature [țipătul literaturii] pe care scrierile lui Hélène Cixous ni-l dezvăluie, explorând rolul semnificativ asumat de sonoritate în aceste descrieri ale vieții non-umane. Pentru Cixous, puterea telefonică a substituției aproape instantanee și prostetică este inseparabilă de sunetele produse de o coterie de animale care populează scrierile acestor doi autori. Ceea ce intrigă este că acest bestiar este aproape întotdeauna rostit cu un anumit grad de omonimie și de omofonie. Astfel, articolul urmărește ceea ce numesc aici „homofaunie”, ca ecou al seriei de calambururi și de neologisme ale lui Cixous: de exemplu, „(t)elefaun” și „(t)elefantazie”, care i-au captat atenția și lui Derrida. Articolul problematizează ce este în joc atunci când teoretizăm viață non-umană - nu doar animalul, dar și planta și așa-zisa viață neanimată - dacă modul de a problematiza trebuie redirecționat către o acordare specifică registrului acustic, în care ascultarea se acordează din nou sub îndrumarea unei omofonii intraductibile. 